\title{
Carbonization temperature and charcoal properties at different positions in rectangular kiln
}

\author{
Aylson Costa Oliveira ${ }^{1} \oplus$, Diego Correa Ramos ${ }^{2} \oplus$, Bárbara Luísa Corradi Pereira ${ }^{1} \oplus$, \\ Angélica de Cássia Oliveira Carneiro²

\footnotetext{
1 Universidade Federal do Mato Grosso, Cuiabá, MT, Brasil. E-mail: aylsoncosta@gmail.com; babicorradi@gmail.com
} \\ 2 Universidade Federal de Viçosa, Viçosa, MG, Brasil. E-mail: diegoengf@gmail.com; cassiacarneiro1@gmail.com
}

ABSTRACT: To increase production and decrease the heterogeneity of charcoal produced in rectangular kilns, the control of carbonization must be carried out based on the kiln internal temperature. The objective of this work was to analyze the maximum carbonization temperature and the time of thermal degradation at temperatures above $290{ }^{\circ} \mathrm{C}$ based on the internal kiln wall temperatures, in addition to evaluating charcoal properties in different positions of a rectangular kiln. Wood from the hybrid Eucalyptus urophylla $\times$ E. grandis at seven years of age was used for carbonization in rectangular kiln where temperature was monitored and controlled. Process parameters and charcoal quality were evaluated in seven positions in the rectangular kiln. Positions 1 and 7 had higher maximum temperature values and thermal degradation time at temperatures above $290{ }^{\circ} \mathrm{C}$ in comparison with the other positions, which presented similar values. There was no significant effect of kiln position on the characteristics of charcoal, which presented average values of $234.61 \mathrm{~kg} \mathrm{~m}^{-3}$ of bulk density; $55.87 \%$ of pieces with size greater than $30 \mathrm{~mm} ; 19.77 \%$ of fines (granulometry $<9.5 \mathrm{~mm}$ ); and $20.80 \%$ of friability, $75.39 \%$ of fixed carbon, $24.37 \%$ of volatile materials, and $0.24 \%$ of ash. It was concluded that the kiln position affects the temperature and time of thermal degradation; however, the control of temperature guarantees the production of homogeneous charcoal throughout the kiln, presenting satisfactory quality for steel industry usage.

Key words: friability; steel; supervisory system

\section{Temperatura de carbonização e propriedades do carvão vegetal ao longo de um forno retangular}

RESUMO: Para aumento da produção e diminuição da heterogeneidade do carvão vegetal produzido em fornos retangulares, o controle da carbonização deve ser realizado com base na temperatura interna do forno. 0 objetivo deste trabalho foi analisar a temperatura máxima de carbonização e o tempo de degradação térmica em temperaturas superiores a $290^{\circ} \mathrm{C}$, com base nas medições interna na parede dos fornos, além de avaliar propriedades do carvão vegetal em diferentes posições de um forno retangular. Utilizou-se madeira do híbrido Eucalyptus urophylla x E. grandis, aos sete anos de idade para carbonizações em fornos retangulares, com monitoramento e controle de temperatura. Os parâmetros de processo e qualidade do carvão vegetal foram avaliados em sete posições correspondentes aos locais de medição da temperatura na parede do forno retangular. As posições 1 e 7, que correspondem às extremidades do forno, tiveram maiores valores de temperatura e tempo de exposição a temperaturas maiores que $290^{\circ} \mathrm{C}$, enquanto nas posições centrais observou-se menor exposição ao calor e menor temperatura máxima, com valores médios semelhantes. Não houve efeito significativo da posição do forno nas características do carvão, que apresentou valores médios de $234,61 \mathrm{~kg} \mathrm{~m}^{-3}$ de densidade a granel; $55,87 \%$ de peças com dimensão maior que $30 \mathrm{~mm} ; 19,77 \%$ de finos (granulometria $<9,5 \mathrm{~mm}$ ) e $20,80 \%$ de friabilidade, $75,39 \%$ de carbono fixo, $24,37 \%$ de materiais voláteis e $0,24 \%$ de cinzas. Conclui-se que a posição do forno afeta a temperatura e tempo de degradação térmica, contudo, o controle da temperatura garante a produção de carvão vegetal homogêneo ao longo do forno, com qualidade satisfatória para uso siderúrgico. 


\section{Introduction}

Brazil is the world's largest producer of wood charcoal and is responsible for $11 \%$ of total production in 2018 , which accounted roughly for 4.6 million tons with $91 \%$ of the product origins being wood from planted forests (IBÁ, 2019). Brazil's position as a leader is due to the use of charcoal as a thermo-reducer input by the steel industry, which provides carbon and energy to reduce iron ore, and it acts as a support structure for the ore load (Figueiró et al., 2019). Additionally, the wood charcoal causes less pollution than the mineral charcoal (Rodrigues \& Braghini Júnior, 2019).

To meet industrial needs, especially the steel industry, forestry companies have sought to achieve greater homogeneity of the raw material by selecting and using species or clones of the genus Eucalyptus (Juízo et al., 2017; Fialho et al., 2019; Ramos et al ., 2019). Another area of study is the development of kilns and optimizing the wood carbonization process (Carvalho et al., 2012; Oliveira et al., 2015; Carneiro et al., 2018), especially the carbonization temperature.

In the last few decades, wood carbonization systems have been improved, resulting in greater use of high-performance rectangular kilns by charcoal producers. The rectangular masonry kilns have a large volumetric capacity, varying from 150 to 550 cubic meters $\left(\mathrm{m}^{3}\right)$ of wood, and this allows for the mechanization of loading and unloading processes, reduces the need for labor, and increases the operational efficiency. These efforts have presented charcoal yields that varying from 30 to $35 \%$, which is considered satisfactory level (Rodrigues \& Braghini Júnior, 2019). However, according to Santos et al. (2017), the large dimensions and larger volumes of wood to be carbonized results in great difficulty in controlling the carbonization process, due to the variation in the heating rate, gas distribution, and kiln temperature.

The carbonization of wood consists of its heating in the controlled presence of oxygen at temperatures above $150^{\circ} \mathrm{C}$ and results in effective charcoal production at temperatures between 350 and $500{ }^{\circ} \mathrm{C}$ (Oliveira et al., 1982). Nevertheless, there is a great variation in the kiln internal temperature during carbonization, presenting higher temperatures in the central and upper regions (Carvalho et al., 2012; Damásio et al., 2015). Thus, controlling the carbonization process based on the internal temperature becomes necessary to increase production and decrease the heterogeneity of charcoal produced in rectangular kilns.

When the carbonization process control utilizes infrared sensors, it is necessary to install metal tubes (Oliveira et al., 2013), which are usually installed on the bottom of the kiln walls. This measure aims to ease access and operationalization of the kiln because when installed at greater heights, they would increase the temperature collection time and also increase the risks to the operator. Thus, lower heights and proximity to the wall can cause thermal losses, and temperatures between 300-350 ${ }^{\circ} \mathrm{C}$ are defined as references for carbonization control. It is important to prevent temperatures in the upper and inner part of the kiln from reaching values above $500{ }^{\circ} \mathrm{C}$, which would result in the degradation of the produced charcoal.
Despite the adoption of temperature control systems in rectangular kilns during the carbonization process, there will be variation in the time that the kiln remains at the established temperature and at the maximum temperature reached. Therefore, the evaluation of charcoal quality produced in industrial kilns becomes important for the development of controlled procedures and determination of the maximum temperature to be measured and achieved in the wall, and this serves to meet the quality and homogeneity parameters required by the steel industry.

Hence, the present study was designed to analyze the maximum carbonization temperature and the time of thermal degradation of the wood at temperatures above $290{ }^{\circ} \mathrm{C}$, based on internal kiln wall measurements. In addition, it aims to evaluate the charcoal characteristics in different positions along the rectangular kiln.

\section{Materials and Methods}

\section{Wood characteristics}

The wood used was a hybrid clone of Eucalyptus urophylla $x$ Eucalyptus grandis at 7 years of age. It was grown at a commercial plant with $3.0 \times 3.0 \mathrm{~m}$ spacing, located in the northern region of Minas Gerais state. The trees were cut into logs of $3.30 \mathrm{~m}$ and left to dry outside for about 90 days.

After drying outside, the logs were transported to the Charcoal Production Unit, where they were weighed and selected for carbonization. When placed in the box close to the kiln, 200 logs were sampled. The diameters were measured, and 20 logs were selected based on their diameter class $(4-10$ and $11-20 \mathrm{~cm})$ in order to be able to remove a 5 $\mathrm{cm}$ disk from the central portion and measure humidity by the greenhouse method. To determine the basic density, 38 logs were sampled. The utilized wood presented average values of basic density equal to $503.3 \mathrm{~kg} \mathrm{~m}^{-3}$, average dry matter basis of $19.20 \%$, and diameter ranging from 4 to 20 inches.

\section{Carbonization}

Six carbonizations were carried out in six rectangular masonry kilns, presenting dimensions of $4.0 \times 26.0 \times 4.5 \mathrm{~m}$ and $1.5 \mathrm{~m}$ (width, length, height, and dome height, respectively) and a capacity to carbonize 360 steric meter (st), approximately about $212 \mathrm{~m}^{3}$ of wood. The kiln had mini-chamber oxygen controllers, two openings at the ends to ignite carbonization, a chimney, and a skylight.

After kiln ignition, the carbonization was conducted between the openings on the ends and the center of the kiln, where the chimney is located (Figure 1). The mini-chamber oxygen controllers were operated as a temperature control valve through limitations of the air intake in the kiln. In the initial phase, the endothermic period of carbonization, the mini-chambers remained partially open to favor the entry of oxygen inside the kiln. After reaching $250{ }^{\circ} \mathrm{C}$, being the transition temperature to the exothermic process, the minichambers were locked to minimize the entry of air in order to maintain a slow heating rate. Once the maximum carbonization 
temperature defined as standard for measurement on the wall was reached, the air inlets in the kiln were completely sealed and the carbonization process ended. Upon complete restriction of air (oxygen) into the kiln, the cooling stage of the charcoal began, which consists of heat exchange between the kiln and environment. At the end of the cooling cycle, the kiln was opened, and the product was removed. The average carbonization time in the rectangular kilns was 16 days - 6 days of carbonization and 10 days for cooling the coal.

The gravimetric yield of each carbonization was determined through the relationship between the mass of charcoal obtained and the dry mass of wood utilized. To determine the volume of semi-carbonized wood, called "atiço", the height, length, and width of the semi-carbonized wood were measured in each position of the kiln, and a factor of 1.7/1.0 was used for conversion from steric meters (st) to cubic meter $\left(\mathrm{m}^{3}\right)$.

\section{Temperature monitoring and control}

The kiln was subdivided into seven carbonization positions. Each carbonization position of the kiln was comprised of the stratified carbonization area with respect to each kiln run, as well as the chimney position for the two central kiln runs. To monitor and measure the internal kiln temperature, 16 metallic cylinders were previously installed on each side - eight on the bottom of the wall at $0.7 \mathrm{~m}$ above the kiln floor, and eight on the median part at $1.9 \mathrm{~m}$ above the kiln floor (Figure 1 ).

Carbonization was carried out with the aid of a temperature control system, and a maximum final temperature target of $380^{\circ} \mathrm{C}$ was used, defined for measuring the internal wall temperature using the metal cylinders. The temperature control consisted of opening and closing the air inlets and monitoring the carbonization by viewing a thermal profile and carbonization time. For greater control of the carbonization process, it was divided into three distinct phases of thermal degradation of the wood: drying and pre-carbonization (temperature up to $250{ }^{\circ} \mathrm{C}$ ), transition period (between 250 and $290^{\circ} \mathrm{C}$ ), and the carbonization itself (temperatures above $290^{\circ} \mathrm{C}$ ). This last period is where exothermic reactions take place. Thus, the maximum carbonization temperature and the time of thermal degradation of the wood with temperatures

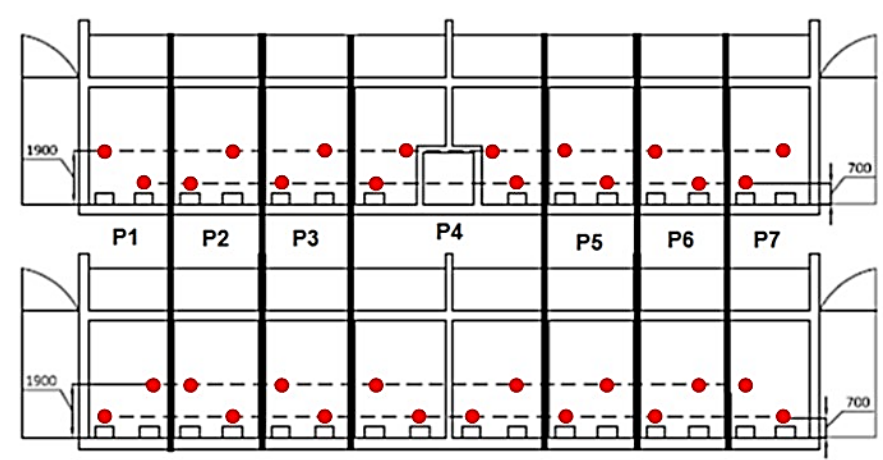

Figure 1. Side view of the rectangular kiln, showing the seven carbonization positions evaluated (P1 to P7) and the internal wall temperature measurement points (in red). Measures in centimeters. greater than $290{ }^{\circ} \mathrm{C}$ measured on the kiln wall were used as evaluation parameters for the carbonization process. The goal was that inside temperatures were above $380^{\circ} \mathrm{C}$ but not higher than $500{ }^{\circ} \mathrm{C}$.

The temperature of the kiln was measured every 3 hours during the entire carbonization cycle, which had an average duration of 3.9 days (94 hours). Temperature measurements and information storages were performed with an infrared temperature measuring device model FLUKE 568.

\section{Sampling and properties of wood charcoal}

To evaluate the quality of the wood charcoal, two samples of 0.01 meters of charcoal were collected for each carbonization position evaluated. To perform the physical and immediate analyses, the charcoal samples, based on position, were homogenized and quartered, and a twenty-liter aliquot was removed from one of the quarters.

Bulk density was determined according to the procedures of the NBR 6922 standards (ABNT, 1981). The granulometry was determined according to the NBR 7402 standards (ABNT, 1982). The entire mass of the charcoal sample was placed in a set of vibrating screens that was sifted for five minutes. The charcoal retained in each screen was collected, and the mass was determined to both quantify material with dimensions greater than $30 \mathrm{~mm}$ and the fraction of fines, which dimensions are below $9.5 \mathrm{~mm}$.

The calculation for the quantification of charcoal with a particle size greater than $30 \mathrm{~mm}$ was performed according to Equation 1.

$$
>30 \mathrm{~mm}(\%)=\frac{\mathrm{Pt}-\mathrm{Pp}}{\mathrm{Pt}} \cdot 100
$$

where: > $30 \mathrm{~mm}$ - percentage of sample larger than $30 \mathrm{~mm}$; $\mathrm{Pt}$ - total sample weight $(\mathrm{Kg})$; $\mathrm{Pp}$ - weight after screening $(\mathrm{Kg})$.

The quantification of the fraction of fines followed the same procedure as in Equation 1. However, the necessary changes to the percentage of the sample with a dimension less than $9.5 \mathrm{~mm}$ was performed.

To determine the charcoal friability index, the drum test was used, according to the methodology of the Minas Gerais Technological Center (Oliveira et al., 1982). Charcoal samples that passed through the $60 \mathrm{~mm}$ screen and were retained in the $30 \mathrm{~mm}$ screen were used. Samples of approximately 500 $\mathrm{g}$ of charcoal were taken to a rotating drum for 16 minutes at 30 rotations per minute ( $\mathrm{rpm}$ ). After this period, the charcoal was screened again, the mass that was retained in the $30 \mathrm{~mm}$ screen was measured, and then, the friability index was calculated according to Equation 2.

$$
\text { Friability }(\%)=\frac{\mathrm{TA}-\mathrm{TP}}{\mathrm{TA}} \cdot 100
$$

where: TP - Charcoal weight between 30 and $60 \mathrm{~mm}$ after the drum method was performed (g); TA - Weight of charcoal between 30 and $60 \mathrm{~mm}$ sampled (g). 
The immediate analysis of charcoal to determine the contents of volatile materials, ash, and fixed carbon was performed according to NBR 8112 standards (ABNT, 1986).

\section{Statistical analysis}

For the evaluation of the charcoal temperatures and characteristics, six carbonizations (repetitions) were carried out, and for each carbonization, seven positions (treatments) were evaluated. Thus, a completely randomized design was used.

The data was submitted to Lilliefors test to test normality, and to the Cochran test to test the homogeneity of variances. Then, the analysis of variance was performed and when a significant effect was verified by the F-test, the Scott-Knott test was applied at a significance level of 0.05 . When there was no significant effect, a descriptive statistical analysis was performed, showing the mean, minimum, maximum, and coefficient of variation.

\section{Results and Discussion}

\section{Carbonization temperature and gravimetric yield}

Figures $2 \mathrm{~A}$ and $2 \mathrm{~B}$ shows the statistical analysis. There was a significant effect of the carbonization position for the final temperature of each carbonization and carbonization time at a temperature above $290{ }^{\circ} \mathrm{C}$, considering the internal temperatures.

Figure 2A illustrates that positions 1 and 7 had values of maximum temperature statistically higher than the other positions. In all carbonization positions, an internal wall temperature above $290{ }^{\circ} \mathrm{C}$ was observed, a value adopted as the lower limit for the third carbonization phase. For the transformation of wood into charcoal, the kilns must remain for a greater proportion of time in a temperature range greater than $290^{\circ} \mathrm{C}$, in relation to the initial phases and, thus, ensure that the interior of the kiln will reach temperatures above $380^{\circ} \mathrm{C}$. According to Oliveira et al., (1982) this promote the effective thermal transformation of wood and production of charcoal. Positions 1 and 7 had average times above 30 hours at temperatures above $290^{\circ} \mathrm{C}$, while the other positions had average times below 20 hours (Figure $2 \mathrm{~B}$ ).

The maximum carbonization temperature (Figure $2 \mathrm{~A}$ ) for each position differed significantly due to the ignition and end zones of the carbonization process. In positions 1 and 7, the temperature measured on the wall reached values above 400 ${ }^{\circ} \mathrm{C}$ because these are the ignition zones for the rectangular kiln, which are proximal to oxygen inlet openings, and the occurrence of combustion reactions, due to the greater need for energy releases. This happens because the carbonization process used is autothermal and part of the material must be consumed and transformed into energy to start the carbonization process, which probably leads to temperatures higher than $500{ }^{\circ} \mathrm{C}$ at these positions.

The lowest maximum carbonization temperature (MCT) of $\left(354{ }^{\circ} \mathrm{C}\right)$ was verified in position 4 , the central region of the rectangular kiln, and this where the chimney is located for the release of gases generated during carbonization (Figure 1 ). Lower temperatures in the most central regions of the kiln (positions 3 to 6 ) occur due to the greater restriction of oxygen entry and, therefore, better control of the internal kiln temperature. This results in internal temperatures closer to 450 to $500{ }^{\circ} \mathrm{C}$, which prevents the degradation of the produced charcoal.

In the evaluation of thermal instrumentation of rectangular kilns to produce charcoal, Carvalho et al. (2012) found variation in the internal temperature at the different positions evaluated and a variation throughout the carbonization process. It is noteworthy that the temperature difference measured on the wall can influence the internal kiln temperature and consequently the semi-carbonized wood, as well as the production and quality of the produced charcoal. However, in the present work (Figure 2A), the difference between the highest and lowest maximum carbonization temperatures was $17 \%$, considering the entire length of the kiln. In addition, temperatures above $430{ }^{\circ} \mathrm{C}$ were not verified in any position on the wall (Figure $2 \mathrm{~A}$ ), ensuring that the temperature inside the kiln did not reach very high temperatures, i.e. above 500 ${ }^{\circ} \mathrm{C}$, which would favor the degradation of the charcoal after
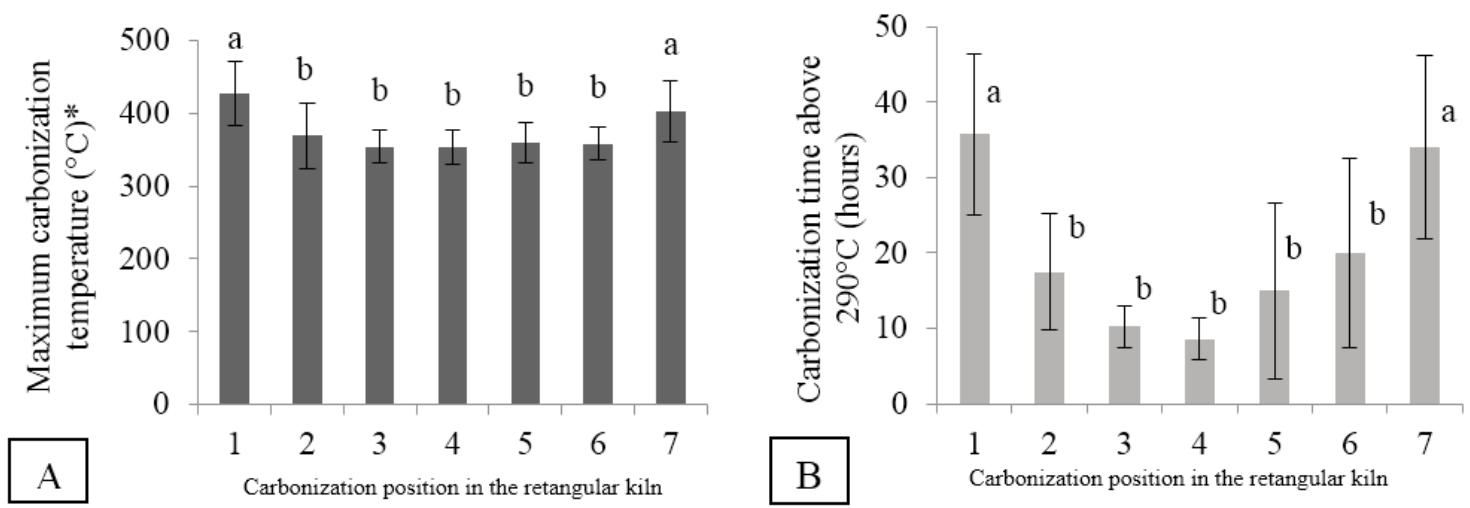

Means followed by at least one same letter do not differ statistically by the Scott-Knott test at $5 \%$ significance.

Figure 2. A - Average values and standard deviation of the maximum carbonization temperature (MCT) as a function of the carbonization position in the rectangular kiln. B - Average wood degradation time at temperatures above $290{ }^{\circ} \mathrm{C}$ depending on the carbonization position in the rectangular kiln. *Determined according to internal kiln wall measurements. 
its formation. According to Moulin et al. (2017) and Dufourny et al. (2019), carbonization temperatures above $450^{\circ} \mathrm{C}$ result in charcoal with a higher fixed carbon content, but there is a reduction in gravimetric yields.

Figure $2 \mathrm{~B}$ shows the thermal degradation time at temperatures above $290{ }^{\circ} \mathrm{C}$. The thermal degradation time at temperatures above $290{ }^{\circ} \mathrm{C}$ was greater at the ends and shorter in the central region of the kiln, which was expected at the operational level. It happens because the wood contained in position 4 and its surroundings, an area close to the chimney location (Figure 1), suffers greater influence from gases generated during the entire carbonization process, requiring less time with high temperatures in the final stage of the process. Despite the shorter time, it can be seen in Figure $2 \mathrm{~A}$ that the central region of the kiln reached maximum temperatures of $350^{\circ} \mathrm{C}$, measured on the wall, and according to Oliveira et al. (2013), the degradation of the wood pulp is intensified when the kiln reach temperatures between 275 and $400{ }^{\circ} \mathrm{C}$, leading to greater production of gases and expressive formation of charcoal. This is because internal kiln temperatures will be higher than the temperatures in the wall.

There is greater time required for wood degradation at temperatures greater than $290^{\circ} \mathrm{C}$ measured on the wall, which were observed in positions 1 and 7 and are due to these areas being the ignition zone of the kiln. In these positions, there is a greater entry of air (oxygen) and results in a combustion region. These position temperatures remain higher during the entire carbonization process, aiming at the generation of energy for the transformation of wood into charcoal throughout the kiln. During the carbonization process, it can be assumed that when the temperature in position 4 reaches $290{ }^{\circ} \mathrm{C}$, in general, positions 1 and 7 are already completely carbonized.

The use of a supervisory system can control the time that the carbonization kiln floor will remain above $290^{\circ} \mathrm{C}$ (temperature measured on the wall and defined as a reference in this work) until the end of carbonization, because according to Carvalho et al. (2012), the carbonization process instrumentation allows for real-time monitoring of the temperature inside the kiln. This contributes to the homogenization of the wood carbonization process of the wood, providing an increase in the kiln productivity and the charcoal quality. However, the processes and behavior in each position must be evaluated considering the inputs, information related to the raw wood material (basic density, humidity, average diameter, and wood volume), and the outputs, information on the final product (gravimetric yield, percentage of semi-carbonized wood, fixed carbon content, apparent density, and friability), in addition to the relationship between temperature measured in the wall and effective temperature in the carbonization floor.

The average charcoal gravimetric yield of carbonizations in a rectangular kiln was $34.44 \%$ (Table 1), a value within the range of 32 to $35 \%$ for rectangular kilns described by Rodrigues \& Braghini Júnior (2019). In evaluating the performance of rectangular kilns equipped with thermocouples to monitor the temperature, Arruda et al. (2011) reported charcoal yield values varying between 23.8 and $28.4 \%$; however, the authors stated that the low yield was due to the high humidity of the wood ( 48 to $66 \%$ ) and temperature of $269^{\circ} \mathrm{C}$ measured close to maximum kiln wall. In the present work, it was observed that the instrumentation was able to obtain the kiln thermal profile during carbonization and an important tool in controlling the temperature. It is important to avoid temperatures above 500 ${ }^{\circ} \mathrm{C}$, as it would result in the degradation of the charcoal and reduction of the gravimetric yield.

Despite the variation in the maximum carbonization temperature and the average degradation time verified throughout the kiln (Figures $2 \mathrm{~A}$ and $2 \mathrm{~B}$ ), the position had no significant effect on the volume of semi-carbonized wood generated. This study presented an average value of $2.21 \mathrm{~m}^{3}$ per carbonization in a rectangular kiln, a value corresponding to $7.03 \%$ of the volume of wood carbonized.

In a charcoal production utilizing a rectangular kiln, the presence of a small percentage of semi-carbonized wood is unavoidable. In order not minimize generation semicarbonized wood in the process, it would be necessary to increase the kiln temperature or keep the air intakes open for a longer time. However, this would result in the degradation of part of the charcoal generated in the upper part of the kiln, resulting in losses of mechanical resistance of charcoal and reduction of its gravimetric yield. In addition, it can cause wear on the kiln structure, increasing the need for maintenance or reducing its useful life.

On the other hand, the high generation of semi-carbonized wood creates a challenge in mechanized removal of charcoal and can eventually cause damage to the kiln structure by the semi-carbonized wood colliding against its masonry. Moreover, separating the semi-carbonized wood from the charcoal becomes difficult, as well as its reutilization. In the steel industry, the presence of the semi-carbonized wood in the charcoal load can cause sticking to the load tubes, that is in other words, tubes that get clogged due to the large size of raw materials that harms the kiln loading process. For carbonization in a rectangular masonry kiln, it is advisable that the volume of semi-carbonized wood generated range between 5 and $10 \%$ of the wood load volume. Accordingly, the volume generated in the evaluated carbonizations had an average value equal to $7 \%$, which is within the acceptable limit.

Table 1. Descriptive statistics of charcoal gravimetric yield (\%) and volume of semi-carbonized wood $\left(\mathrm{m}^{3}\right)$ of carbonizations in a rectangular kiln.

\begin{tabular}{lcc}
\hline $\begin{array}{c}\text { Statistic } \\
\text { variables }\end{array}$ & $\begin{array}{c}\text { Charcoal } \\
\text { gravimetric } \\
\text { yield }(\%)\end{array}$ & $\begin{array}{c}\text { Volume } \\
\text { of semi-carbonized } \\
\text { wood }\left(\mathbf{m}^{\mathbf{3}}\right)\end{array}$ \\
\hline Mean & 34.44 & 2.21 \\
Minimum & 33.07 & 0.89 \\
Maximum & 35.48 & 4.06 \\
Variation coefficient & $2.48 \%$ & $54.94 \%$ \\
\hline
\end{tabular}




\section{Charcoal quality}

The charcoal physical properties did not present any significant difference in any position of the rectangular kiln (Table 2), indicating adequate temperature control and monitoring of carbonization despite difficulty based on rectangular kiln dimensions and the temperature differentiation measured along the wall length (Figures $2 \mathrm{~A}$ and $2 \mathrm{~B})$. Monitoring the internal temperature of the carbonization kiln provides increased process efficiency, standardization, and improved charcoal quality (Arruda et al. 2011).

The average bulk density of charcoal in this study (Table 2) was higher than that observed by Figueiró et al. (2019), who found average values ranging from 180 to $205 \mathrm{~kg} \mathrm{~m}^{-3}$ when characterizing the charcoal properties produced in rectangular industrial kilns. However, this difference can be attributed to the difference in the carbonization conduction or temperature, granulometric distribution and humidity of the analyzed charcoal, as well as the wood used as raw material.

According to Carneiro et al. (2013), uses the bulk density must be greater than $200 \mathrm{~kg} \mathrm{~m}^{-3}$ for the steel industry, and thus, it appears that the density of charcoal produced in rectangular kilns was $17 \%$ above this limit, allowing for its use in the steel industry. The higher charcoal density results in greater load capacity in the blast furnace in terms of carbon by volume. However, the very high density of the charcoal can impair the permeability of the load and gas distribution along the blast furnace. Thus, it is important to perform a weighted assessment of the qualitative parameters of the wood charcoal, considering the productivity responses of the metallurgical furnace and the final cost of the product.

The average percentage of charcoal with dimensions greater than $30 \mathrm{~mm}$ was $55.87 \%$ and varied up to $14.62 \%$ (Table 2). This value is considered satisfactory for production in larger industrial kilns that perform mechanized unloading, since charcoal is a very reliable material and susceptible to breaking during use.

Charcoal granulometry, studied by Braga (1979), is a relevant characteristic for the productivity of the industrial blast furnace. A coarse fraction (over $32 \mathrm{~mm}$ ) greater than $40 \%$ is desirable, which was achieved in this work. The use of larger charcoal favors the aeration of the load in the blast furnace. According to Picancio et al. (2018), it is necessary that the load in the blast furnace is uniformly permeable to gases in the production of pig-iron. Therefore, the adequate charcoal granulometry gives greater permeability in the load and consequent gas distribution, guaranteeing the efficiency of iron ore reduction reactions.
The average fines production values, charcoal smaller than 9.5 millimeters, was $19.77 \%$ with a variation of $27.25 \%$ (Table 2). Figueiró et al (2019) determined the properties of charcoal produced in rectangular industrial kilns and found average values of fines equal to $20.75 \%$ for a kiln with $500 \mathrm{~m}^{3}$ of wood and $23.79 \%$ for a kiln of $180 \mathrm{~m}^{3}$, presenting an average variation of $40 \%$.

In this work, the values obtained were close to $20 \%$, and this may be attributed to the unloading the charcoal, which occurs mechanically in rectangular kilns. According to Figueiró et al. (2019), greater movement of the charcoal results in more breaks and, consequently, greater fines content. In addition to handling, generation of charcoal fines in masonry furnaces is also affected by the carbonization temperature. Siebeneichler et al. (2017) found that the increase in both temperature and heating rate increases the occurrence of ruptures in the charcoal structure, consequently reducing their physical resistance.

Despite the significant difference in the maximum carbonization temperature and degradation time between the measured carbonization positions (Figure 2), there were no differences in the generation of fines throughout the kiln. It can be said that the temperature variation in the different positions was not enough to promote the degradation of charcoal within the magnitude of industrial production in the rectangular kiln, maintaining the charcoal quality.

In the steel industry, charcoal fines are considered byproducts, which are screened and removed in the process, and this can cause their accumulation in the charcoal production unit. Thus, a higher fines percentage results in greater generation of residues. However, the fines can be marketed to cement and ceramics plants or even be used as auxiliary fuel in the blast furnace nozzles to be used as a heat source.

In this study, the average charcoal friability value was equal to $20.8 \%$ (Table 2 ), being characterized as medium strength material according to the CETEC classification, Oliveira et al. (1982). Damásio et al. (2015) determined the friability of eucalyptus charcoal produced in a circular kiln with carbonization temperature control, and the researchers obtained an index of $15.28 \%$, which is similarly classified as medium resistance.

The temperature control by the supervisory system that allowed for carbonization to occur at moderate temperatures (Figure 2A) may have favored the mechanical resistance of the charcoal, resulting in the intermediate friability value (Table 2). According to Noumi et al. (2016), higher carbonization

Table 2. Descriptive statistics of the quality parameters of the wood charcoal produced in carbonizations in a rectangular kiln.

\begin{tabular}{ccccc}
\hline Statistic variables & $\begin{array}{c}\text { Bulk density } \\
\left(\mathbf{k g} \cdot \mathrm{m}^{-3}\right)\end{array}$ & $\begin{array}{c}\text { Granulometric greater } \\
\text { than 30mm (\%) }\end{array}$ & $\begin{array}{c}\text { Fine* } \\
(\%)\end{array}$ & $\begin{array}{c}\text { Friability } \\
(\%)\end{array}$ \\
\hline Mean & 234.61 & 55.87 & 19.77 & 20.80 \\
Minimum & 228.09 & 50.14 & 18.03 & 18.40 \\
Maximum & 241.13 & 59.53 & 22.34 & 23.88 \\
Coefficient of variation & $6.44 \%$ & $14.62 \%$ & $27.25 \%$ & $16.89 \%$ \\
\hline
\end{tabular}

*Fine: grain size less than $9.5 \mathrm{~mm}$. 
temperature results in a higher charcoal friability index, due to the disruption of the wood cell walls during the process. In addition to the temperature, the low wood raw material humidity (19.20\%) may have influenced this property because higher wood moisture levels increase friability. This is because they are associated with high speeds of gas expansion during carbonization, which generally causes breaks in the resulting charcoal structure and makes it more brittle.

Charcoal with high friability is not recommended for use in the steel industry because it will have less mechanical stability and increase the generation of fines during handling and transport, thus also making screening necessary. In addition, fines reduce the permeability of the loading floor in the blast furnace, negatively affecting the efficiency of the steelmaking process (Dufourny et al. 2019).

There was no significant effect of the carbonization position for the contents of fixed carbon, volatile materials, and ash of the charcoal produced in the carbonizations evaluated in a rectangular kiln (Table 3 ), despite the significant difference in the final temperature and the degradation time among the measurements taken in the kiln (Figure 2).

The produced wood charcoal had an average fixed carbon value equal to $75.39 \%$, and this value was close to that verified by Arruda et al. (2011) and Figueiró et al. (2019), who evaluated the quality of eucalyptus charcoal produced in rectangular kilns with temperature control. The fixed carbon value found was adequate, as the average percentage for using charcoal as an input for the steel industry should vary between 70 and 75\% fixed carbon (Carneiro et al., 2013; Santos et al. 2016).

The average value and the low coefficient of variation for both the friability intermediate value (Table 2) the fixed carbon (Table 3) verified in this work, demonstrated that the internal temperature control performed on the walls (Figure 2) prevented that very high temperatures (above $500{ }^{\circ} \mathrm{C}$ ) were reached inside, which would increase the fixed carbon and reduce the mechanical strength. According to Dias Júnior et al. (2016) and Noumi et al. (2016), this would be the expected result of higher carbonization temperature, as higher temperatures result in higher fixed carbon content of the produced charcoal, and fixed carbon contents above $80 \%$ are observed above $500{ }^{\circ} \mathrm{C}$. Moreover, Siebeneichler et al. (2017) stated that the increase in the temperature reduces the charcoal resistance.

The average volatile materials content of $24.37 \%$ is suitable for the use of charcoal for steel, since this parameter has an

Table 3. Descriptive statistics of the contents of fixed carbon, volatile materials, and fixed carbon of wood charcoal produced in carbonizations in a rectangular kiln.

\begin{tabular}{lccc}
\hline \multicolumn{1}{c}{ Statistic variables } & $\begin{array}{c}\text { Fixed } \\
\text { carbon (\%) }\end{array}$ & $\begin{array}{c}\text { Volatile } \\
\text { materials (\%) }\end{array}$ & $\begin{array}{c}\text { Ash } \\
\text { (\%) }\end{array}$ \\
\hline Mean & 75.39 & 24.37 & 0.24 \\
Minimum & 68.59 & 16.96 & 0.07 \\
Maximum & 82.71 & 31.22 & 1.36 \\
Coefficient of variation & $4.17 \%$ & $12.93 \%$ & $79.91 \%$ \\
\hline
\end{tabular}

inverse relationship with fixed carbon, and the recommended for an adequate quality of charcoal would be values varying from 25 to 30\%. Figueiró et al. (2019) found volatile material values ranging from 25 to $27 \%$ when characterizing the properties of wood charcoal produced in rectangular industrial kilns.

In this study, the average ash content was $0.24 \%$, and this chemical property presented the highest variation coefficient (Table 3). Arruda et al. (2011) found an average value of $0.57 \%$ for charcoal produced in two carbonization processes in rectangular kilns. On the other hand, Figueiró et al. (2019) found average values ranging from 1.23 to $1.50 \%$, and these higher values are attributed to the presence of contaminants from the kiln floor and the stockyard wood charcoal.

The produced charcoal would be suitable for steel industry uses, as it has a value of less than $0.3 \%$ of ash. For uses as an input in the steel industry, the presence of inorganic materials in charcoal should be kept to a minimum, which in addition to reducing its calorific value, causes wear in the blast furnace and can compromise the quality of the pig-iron with consequent formation of cracks and fissures (Carneiro et al., 2013). Dias Júnior et al. (2016) did not observe a significant effect of the carbonization temperature on the ash content of wood charcoal produced with eucalyptus wood, obtaining values ranging from 0.24 to $0.49 \%$, and this indicates that this property is more affected by the wood raw material and contamination after production.

\section{Conclusions}

Based on measurements taken close to the kiln wall, the maximum carbonization temperature and the wood degradation time at temperatures above $290{ }^{\circ} \mathrm{C}$ were higher at the ends of the rectangular kiln, while the variations at the central part were not significant.

The monitoring and controlling of the carbonization temperature on the walls of the rectangular kilns ensured the production of homogeneous charcoal throughout the kiln, presenting low production of semi-carbonized wood and satisfactory quality for steel industry usages.

\section{Acknowledgements}

The authors would like to thank for their support: CAPES; CNPq; FAPEMIG; the company MinasLigas; the Graduate Program in Forest Engineering - UFV, the Laboratório de Tecnologia da Madeira - FENF / UFMT and Michael James Stablein of the University of Illinois Urbana-Champaign for his translation services and review of this work.

\section{Literature Cited}

Arruda, T. P. M.; Pimenta, A. S.; Vital, B. R.; Lucia, R. M. D.; Acosta, F. C. Avaliação de duas rotinas de carbonização em fornos retangulares. 2011. Revista Árvore, v.35, n.4, p.949-955, 2011. https://doi.org/10.1590/S0100-67622011000500020. 
Associação Brasileira de Normas Técnicas - ABNT. NBR 6922: Carvão vegetal: ensaios físicos determinação da massa específica (densidade a granel). Rio de Janeiro: ABNT, 1981. 2p.

Associação Brasileira de Normas Técnicas - ABNT. NBR 7402: Carvão vegetal: determinação granulométrica. Rio de Janeiro: $A B N T$, 1982. 3p.

Associação Brasileira de Normas Técnicas - ABNT. NBR 8112: carvão vegetal: análise química imediata. Rio de Janeiro: ABNT, 1986. $5 p$.

Braga, R. N. B. Os parâmetros de qualidade do carvão vegetal e seus reflexos na produção de gusa. Piracicaba: IPEF, 1979. p.33-48. (IPEF. Circular Técnica, 73).

Carneiro, A. C. O.; Vital, B. R.; Oliveira, A.C.; Pereira, B. L. C. Pirólise lenta da madeira para produção de carvão vegetal. In: Santos, F.; Collodette, J.; Queiroz, J.H. (Eds.). Bioenergia \& biorrefinaria - cana-de- açúcar \& espécies florestais. 1.ed. Viçosa: Os Autores, 2013. p.429-457.

Carneiro, A.C.O; Donato, B.D.; Valência, A.R.; Barcellos, D.C.; Silva, C.H.F.; Cunha, W.L.P. Monitoring of transportation network of carbonization gases in cogeneration projects. Revista Árvore, v.42, n.6, e420601, 2018. https://doi.org/10.1590/180690882018000600001.

Carvalho, S.R.; Borges, V.L.; Mulina, B.H.O.; Oliveira, R.L.M.; Figueira Júnior, E.A.; Pessoa Filho, J.S. Instrumentação térmica aplicada ao processo de produção de carvão vegetal em fornos de alvenaria. Revista Árvore, v.36, n.4, p.787-796, 2012. https://doi. org/10.1590/S0100-67622012000400020.

Damásio, R. A. P.; Oliveira, A.C.; Carneiro, A.C.O.; Barcelos, D.C.; Pereira, B.L.C.; Magalhães, M.A; Silva, C.M.S. Perfil térmico e controle da carbonização em forno circular por meio da temperatura. Ciência da Madeira, v. 6, n. 1, p. 11-22, 2015. https://doi.org/10.12953/2177-6830/rcm.v61p11-22.

Dias Júnior, A. F.; Pirola, L. P.; Takeshita, S.; Lana, A. Q.; Brito, J. O.; Andrade, A. M. Higroscopicity of charcoal produced in different temperatures. Cerne, v,22, n. 4, p. 423-430, 2016. https://doi.org /10.1590/01047760201622032175.

Dufourny, A.; Van De Steene, L.; Humbert, G.; Guibal, D.; Martin, L.; Blin, J. Influence of pyrolysis conditions and the nature of the wood on the quality of charcoal as a reducing agent. Journal of Analytical and Applied Pyrolysis, v. 137, p. 1-13, 2019. https:// doi.org/10.1016/j.jaap.2018.10.013.

Fialho, L. F.; Carneiro, A. C.O.; Figueiró, C.G.; Carneiro, A.P.S.; Surdi, P.G.; Vital, B.R.; Magalhães, M.A.; Peres, L.C. Application of thermogravimetric analysis as a pre-selection tool for Eucalyptus spp. Revista Brasileira de Ciências Agrárias, v.14, n.3, e6363, 2019. https://doi.org/10.5039/agraria.v14i3a6363.

Figueiró, C. G.; Carneiro, A.C.O.; Santos, G.R.; Carneiro, A.P.S.; Fialho, L. F.; Magalhães, M.A.; Silva, C.MS.; Castro, V.R. Caracterização do carvão vegetal produzido em fornos retangulares industriais. Revista Brasileira de Ciências Agrárias, v.14, n.3, e5659, 2019. https://doi.org/10.5039/agraria.v14i3a5659.

Indústria Brasileira de Árvores - IBÁ. Relatório 2019. São Paulo: IBÁ, 2019. 78p. https://iba.org/datafiles/publicacoes/relatorios/ibarelatorioanual2019.pdf. 06 Apr. 2020.
Juízo, D.G.F.; Lima, M.R.; Silva, D.A. Qualidade da casca e da madeira de nove espécies de Eucalipto para produção de carvão vegetal. Revista Brasileira de Ciências Agrárias, v.12, n.3, p.386390, 2017. https://doi.org/10.5039/agraria.v12i3a5461.

Moulin, J.C.; Nobre, J.R.C.; Castro, J.P.; Trugilho, P.F.; Arantes, M.D.C. Effect of extractives and carbonization temperature on energy characteristics of wood waste in Amazon rainforest. Cerne, v. 23, n. 2, p. 209-218, 2017. https://doi.org/10.1590/010477602017 23022216.

Noumi, S.; Rousset, P.; Carneiro, A. D. C. O.; Blina, J. Upgrading of carbon-based reductants from biomass pyrolysis under pressure. Journal of Analytical and Applied Pyrolysis, v. 118, p. 278-285, 2016. https://doi.org/10.1016/j.jaap.2016.02.011.

Oliveira, A. C.; Carneiro, A.C.O; Barcellos, D.C.; Rodriguez, A.V.; Amaral, B.M.N.; Pereira, B.L.C. Resfriamento artificial em fornos retangulares para produção de carvão vegetal. Revista Árvore, v.39, n.4, p.769-778, 2015. https://doi.org/10.1590/010067622015000400020.

Oliveira, A.C.; Carneiro, A.C.O.; Pereira, B.L.C.; Vital, B.R.; Carvalho, A.M.M.L.; Trugilho, P.F.; Damásio, R.A.P. Otimização da produção do carvão vegetal por meio do controle de temperaturas de carbonização. Revista Árvore, v.37, n.3, p.557-566, 2013. https:// doi.org/10.1590/S0100-67622013000300019.

Oliveira, J. B.; Vivacqua Filho, A.; Gomes, P. A. Produção de carvão vegetal - aspectos técnicos. In: penedo, W.R. (Ed.). Produção e utilização do carvão vegetal. 1982. Belo Horizonte: CETEC, 1982. p. 60-73. (CETEC. Série de Publicações Técnicas, 8).

Picancio, A.C; Isbaex, C; Silva, M.L; Rêgo, L.J; Silva, L.F. Controle do processo de produção de carvão vegetal para siderurgia. CAD, v. 12, n.1., 2018. https://revistas.pucsp.br/caadm/article/ view/31654/26756. 09 Apr. 2020.

Ramos, D. C.; Carneiro, A. D. C. O.; Tangstad, M.; Saadieh, R.; Pereira, B. L. C. quality of wood and charcoal from Eucalyptus clones for metallurgical. Floresta e Ambiente, v. 26, n. spe2, p. e20180435, 2019. https://doi.org/10.1590/2179-8087.043518.

Rodrigues, T.; Braghini Júnior, A. Charcoal: A discussion on carbonization kilns. Journal of Analytical and Applied Pyrolysis, v. 143, e104670, 2019. https://doi.org/10.1016/j. jaap.2019.104670.

Santos, R.C.; Carneiro, A.C.O.; Vital, B.R.; Castro, R.V.O.; Cidaurre, G.B.; Trugilho, P.F.; Castros, A.F.N.M. Influência das propriedades químicas e da relação siringil/guaiacil da madeira de eucalipto na produção de carvão vegetal. Ciência Florestal, v.26, n.2, p.657669, 2016. https://doi.org/10.5902/1980509822765.

Santos, S.F.O.M.; Piekarski, C.M.; Ugaya, C.M.L.; Donato, D.B.; Braghini, A.; Francisco, A.C.; Carvalho, A.M.M.L. Life cycle analysis of charcoal production in masonry kilns with and without carbonization process generated gas combustion. Sustainability, v.9, n.9, e1558, 2017. https://doi.org/10.3390/su9091558.

Siebeneichler, E. A.; Costa, L. M. D.; Figueredo, N. A.; Tronto, J.; Rocha, P. A. Influence of temperature and heating rates on mechanical resistance, density and yield of the wood charcoal of Eucalyptus cloeziana. Revista Ciência da Madeira, v. 8, n. 2, p. 82-94, 2017. https://doi.org/10.12953/2177-6830/rcm.v8n2p82-94. 